\title{
Post-Pandemic of Covid-19 and the Need for Transforming Education 5.0 in Afghanistan Higher Education
}

\author{
Mohammad Naim Rahim \\ Kunduz University, Kunduz 3501, Afghanistan \\ mnaim.rahim@gmail.com
}

\section{ARTICLE HISTORY}

$\begin{array}{ll}\text { Received } & : 2021-02-13 \\ \text { Revised } & : 2021-03-23 \\ \text { Accepted } & : 2021-03-27\end{array}$

\section{KEYWORDS}

Covid-19

IR 5.0

Education 5.0

Transformation

$21^{\text {st_Century Skills }}$

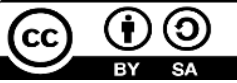

\begin{abstract}
The study is proposed to investigate Education 5.0 and the higher education circumstances in Afghanistan. Today, the mission of education is changed, everything is just a click away, one can google the right answer, hence, and there is an urgent need for redefining the national educational objectives and establishing new goals that are aligned with the new norms. Indeed, $21^{\text {st-century }}$ learners are involved in teaching and learning that cooperates with their head, hearth, and hands. Therefore, the study utilized a qualitative critical document analysis using public records, personal documents, and physical evidence to build an authentic understanding of the on-going paradigm shifts in education and to provide practical potentials for transformation Education 5.0 in the Higher Education of Afghanistan. The data is analyzed based on the procedure of defining research questions, data collection, data transcriptions, coding, and identifying the themes. The result shows that an essentialist-curriculum of teaching and testing is used in Afghanistan. The assessment approaches are included $10 \%$ of class activity and attendance, $10 \%$ of assignments and projects, $20 \%$ of the mid-term exam, and $60 \%$ of the final exam which indicates exam-oriented education. The finding also highlights that the students' needs

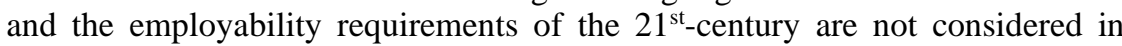
teaching and learning circumstances. In conclude, the study recommends the use of three categories of $21^{\text {st }}$-century skills such as Learning Skills, Literacy Skills, and Life Skills to help educational institutions towards the transformation of Education 5.0. This contributes to preparing learners for the post-pandemic of Covid-19 and employability requirements of the $21^{\text {st-century }}$ marketplace.
\end{abstract}

\section{Introduction}

A leading discourse of education is growing with the help of ICT (Information Communication Technology) and AI (Artificial Intelligence). This educational discourse integrates the potentials of the fifth generation of education (Education 5.0) with the fifth generation of the industrial revolution (IR 5.0) that develops the hypothesis of Knowledge is Downloadable (Harari, 2019). This discourse is not yet easy to understand, especially in the third-world countries like Afghanistan, but since there is no limitation in the advancement of ICT and AI, it will soon change or has already changed teaching and learning practices of these countries. In addition, this educational discourse addresses the intensive enhancement in the fields of science (applied sciences) which is intending to conquer beyond the earth. Initially, the complex knowledge that has been screened for centuries and now is stored in the Cloud Storage can be simply analyzed with the help of ICT and AI (Harari, 2019). Currently, the ability to analyze "Big-Data" has been taken from the humanscientist due to the rapid influence of the great companies such as Amazon, Facebook, and Alibaba. If $\mathrm{AI}$ is empowered to create and analyze "SuperData" by the capability of its consciousness, the human-scientist will be a completely incapable being. As a result, teacher as an authority of the knowledge in the classrooms will be an invalid concept of education anymore.

Therefore, the potential presence of educators in schools and universities with limited knowledge and skills is decreased as the inclusive use of ICT and AI is globalized. The idea of being the authority of knowledge will also be demotivated since ICT and AI will professionally facilitate teaching and learning platforms. So the future educators are those who develop certain skills of the learners not the knowledge itself. The knowledge is now detectable by the learners themselves, and through the potential use 
of these skills they learn and promote. Considering this educational paradigm-shift and the need for transformation Education 5.0, the current study extends the body of literature and provides an authentic understanding of the current status of the higher education circumstances in Afghanistan.

Furthermore, before the Covid-19 pandemic and in the beginning of the $21^{\text {st }}$ century, educational modules has been changed in the world. This paradigm-shift has taken place without considering the communities as developed countries, developing countries, or undeveloped countries. As Rahim \& Sandaran (2020) stated that it does not matter if you are living in a third-world country or first-world, the global educational paradigm-shift has proceeded as a whole event. However, this paradigm-shift may has only appeared in the educational system of some countries, but originally it has restructured the educational context and the content (Rahim \& Sandaran, 2021). Moreover, as people have used the first-generation (1G) of telecommunication and internet technologies to its fifth-generation $(5 \mathrm{G})$, so they did the education. From the first industrial revolution (IR 1.0) of the late 1760s in Europe and the United States which was aligned with the use of mechanization, steam power, and weaving loom until the latest industrial revolution (IR 5.0) in 2020 which is aligned with the applicable use of ICT and artificial intelligence, education enters to its fifth-generation of (Education 5.0) (Rüfenacht, 2021). Despite all these educational innovations and developments, educational perceptions, curriculums, teaching and learning modules, skills, and assessments have remained traditional in Afghanistan.

Therefore, the Covid-19 pandemic has provided a wide opportunity for nations to redefine religious views, cultural perspectives, social taboos, and of course, educational circumstances. Indeed, Covid-19 pandemic has raised a new global need and requirement for both education and employability. According to Rahim (2021), the new norms requires schools and institutions to align their educational objectives with the students' needs globally. In the context of Afghanistan, Covid-19 has also functioned as an ice-breaker for institutions to realize this global need. As a result, this study attempts to investigate transforming Education 5.0 in higher education of Afghanistan.

Echoing the above explanation this present study is aimed to conducted qualitative critical document analysis using public records, personal documents, and physical evidence. The analysis provides an indepth understanding of the current status of educational transformation in the higher education of Afghanistan. It also investigates the industrial revolutions and educational development, paradigmshift in teaching and learning methods, developing theories of teaching and learning, generation classifications, and the use of $21^{\text {st }}$-century skills for implementing Education 5.0. Therefore, this study aimed to highlighted these major points (1) Investigate Education 5.0 and the higher education circumstances in Afghanistan context, (2) Determine the pre-requisite skills for educational transformation, (3) Demonstrate how Education 5.0 helps students in the post-pandemic of Covid-19. Nevertheless, the study is guided by the following main research questions: (a) What is Education 5.0?, (b) What are the required skills to transform Education 5.0?, and (3) How does Education 5.0 prepare learners to survive in the post-pandemic of Covid-19?

\subsection{Significance of the Study}

The study provides an in-depth understanding of Education 5.0 and educational transformation in the higher education of Afghanistan. This contributes to the efforts for educational transformation based on the new educational reforms. It also helps researchers, scholars, educators, students, and educational institutions to prepare for the post-pandemic of Covid19.

\subsection{Conceptual Framework}

The following conceptual framework is formulated for this qualitative study.

Figure 1.1 Conceptual Framework of the Study
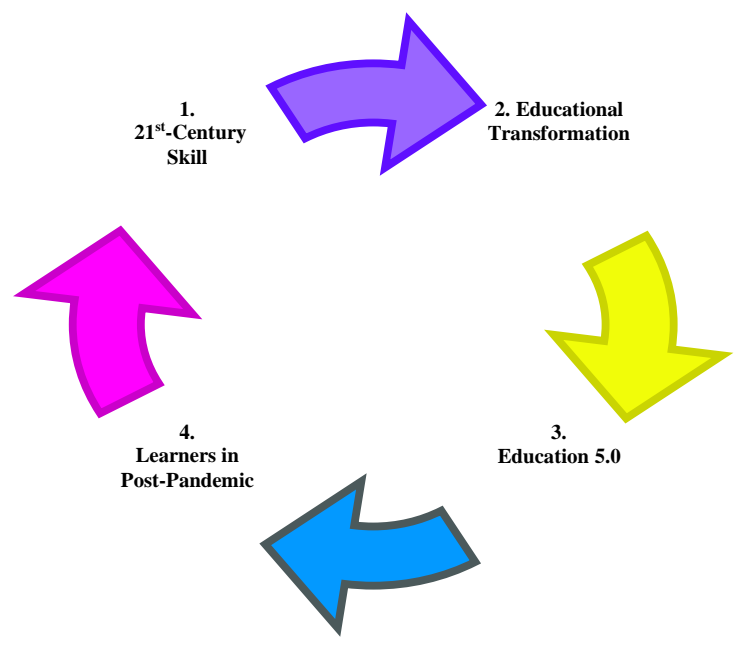

Figure 1.1 indicates the conceptual framework of the study and the relationship between the key concepts. The potential use of $21^{\text {st }}$-century skills accelerates educational transformation and leads to the implementation of Education 5.0 which is aligned with students need and empolyability requrements globally. As a result, Education 5.0 prepares students for the post-pandemic of Covid-19.

\section{Literature Review}

Based on the previous studies, this section discusses Education 1.0 to Education 5.0 each in four perspectives of the industrial revolution and educational development, teaching and learning methods, theories of learning, classification of the 
generations, and skills needed in each of the educational ages.

\subsection{Education 1.0}

The first generation of education (Education 1.0) is aligned with the process of the first industrial revolution (IR 1.0) in the 1760s. According to Aziz Hussin (2018), during the first industrial revolution (IR 1.0), water and steam power were used to mechanize production. Hence, the demands of the marketplace (factories) for employability are limited to the mechanization of water steam power (OECD, 2018). However, there is no formal education yet, but homeschooling has fulfilled the needs by preparing the children who are competent with specific skills and knowledge. These educations have been expensive and limited to specific hours of the week for royal families. Children with poor family backgrounds did not have the chance for education or in some cases they just learned the available knowledge and skills in their surroundings (Watson, 2017). Therefore, teaching and learning are also limited to particular methods, theories, and skills in this period.

\subsubsection{Methods Associated with Education 1.0}

Since there is limited formal education, it is difficult to discuss the methods applied in teaching and learning during this period. Initially, teaching is used as an authority to transfer knowledge and morals to the children in this period (Twenge et al, 2004). It is not yet teacher-centered nor students-centered since educators are considered as the authority of the knowledge and skills. According to $\mathrm{Yu} \&$ Miller (2003), formal education has been available even to the poorest families later in 1800s. The study also stated that there has been two hours of school classes for 10-year-old children in Britain. However, it differs from country to country in this period.

\subsubsection{Theories Associated with Education 1.0}

The need for professional education is not yet theorized. Later in 1833, Britain Government passes the Factory Act making two hours of education a day compulsory for children who are working in factories (Datin et al., 2017). In 1844, the Ragged Schools Union sets up to give schooling to very poor children. This is exactly the time when the importance of education is highlighted as a whole for community members (Rahim, 2019). Still, the focus is on an essentialist-based curriculum with related methods of teaching and testing.

Basically, the foundation of an essentialist curriculum is based on traditional disciplines such as math, natural science, history, foreign language, and literature (Fisk, 2017). Essentialists argued teacheroriented classroom setups. The teachers or administrators decide what is most important for the learners to learn with little regard to the student interests. The teachers also focus on achievement test scores as a means of evaluating progress. According to Kumaravadivelu (2004), this system requires learners to sit in rows. Teaching and learning is facilitated in masses where the number of students per class and educational needs are not evaluated. As a result, the students learn passively by sitting at their desks and listening to the teacher (Rahim, 2020).

\subsubsection{Generation Classifications Associated with Education 1.0}

According to the generation's classifications, children from 1885 to 1900 are categorized as the Lost Generation. Initially, key differences exist in the work values and beliefs of students and employees from different generations, and that failure to address these differences can lead to conflict in the workplace, misunderstanding, miscommunication, lower employee productivity, poor employee well-being and reduced organizational citizenship behavior (Adams, 2000; Bradford, 1993; Fyock, 1990; Jurkievicz, 2000; Kupperschmidt, 2000; Smola \& Sutton, 2002; Yu \& Miller, 2003). Therefore, it is important to consider the generation classifications and their needs and skills within each of the educational periods.

\subsubsection{Skills Associated with Education 1.0}

Since it is an unknown period of education history, therefore, the skills and knowledge are not specific enough. Based on the industrial revolution (1.0), the factories needed employees with skills that are aligned with machinery production by steam power. Later in the 1900s, some of the universities founded in Britain concentrating on skills such as science, engineering, history, and classic. According to Derek \& Schmidt (2020), Education 1.0 is similar to the first generation of the Web, a largely one-way process. In the generation of Web, students go to school to get education from teachers who supply information in the form of a standup routine that may include the use of class notes, handouts, textbooks, videos, and the World Wide Web. Students are large consumers of information resources that are delivered to them, and although they may engage in activities based around those resources. Those activities are for the most part undertaken in isolation or isolated local groups (Rumbidzai, 2020). As the result, these activities contribute back to the information resources that students consume in carrying them out.

\subsection{Education 2.0}

The second generation of education (Education 2.0) from the $1870 \mathrm{~s}$ to $1900 \mathrm{~s}$ leads to the transformation of the second industrial revolution (IR 2.0) which is aligned with mass production, assembly line, and electrical energy. According to Aziz Hussin (2018), during the second industrial revolution (IR 2.0), electric power is used to create mass production. Education 2.0 is also aligned with the development of this industrial revolution during the 1870 s. Since it is 
time that formal schooling and later on the 1900s, universities also have also founded, therefore, the skills and knowledge for employability are improved.

\subsubsection{Methods Associated with Education 2.0}

In this period, pre-scientific methods are developed. Pre-scientific methods are those that are not based on linguistics and psychology theories yet. These methods are teachers' dominant. In the context of second language acquisition, methods such as the grammar-translation method (GTM) is a pre-scientific method. Using this method, classes are taught by the influence of native language with little active use of the target language (Stern, 1983). Much vocabulary is taught in the form of lists of isolated words. Long elaborate explanations of the intricacies of grammar are given. Direct Method (DM) which indicates teaching vocabulary through pantomiming, real-life objects, and other visual materials is also a prescientific method (Richards, 2001). Finally, audiolingual method (ALM) in which speech is more basic to language than the written form is the last prescientific method. According to Krashen \& Terrell (1983), language structure and form are more significant than meaning in this period. Indeed, ALM is a meaningful move towards the use of scientific methods in language classrooms.

\subsubsection{Theories Associated with Education 2.0}

Since the grammar-translation method focuses on translation, memorization, reading, repetitions, and later on, direct method and audio-lingual methods are providing learners with reputations drills, therefore, it is time for the use of behaviorism theory which is developed by (Pavlov \& Skinner, 1930s). The dominant metaphor for behaviorism is carrot and stick It is also associated with the audiolingual method. Students are required repetition, avoidance of error, and corrections. The repetition itself is one of the dominant dimensions of behaviorism theory (Pavlov \& Skinner, 1930s).

\subsubsection{Generation Classifications Associated with Education 2.0}

Based on the generations classifications, children in the age of Education 2.0 are somewhere between Interbellum Generation from 1901 to 1915 and Greatest Generation from 1916 to 1931 (Wong et al., 2008). During this period, aircraft is invented by scientist and land-travel is switched with the ease of airplanes. According to Wong et al. (2008), a generational group shares historical and social life experiences which affect the way people in that generation develop and distinguish one generational group from another. Hence, the needs, educational experiences, and dominant skills between these generations can be similar.

\subsubsection{Skills Associated with Education 2.0}

In the age of Education 2.0, there are facilities for publication of books, magazines, and of course press. Therefore, there is a need for reading skills, memorization skills, repetition drills, and corrections (Prabhu, 1990). Schools and universities required students to practices these skills. The marketplace demand is also aligned with industrial revolution 2.0 and Education 2.0 that required employees to be competent with skills in mass production, assembly line, and electrical energy (Fadel, 2008).

\subsection{Education 3.0}

The third generation of education (Education 3.0) during $1969 \mathrm{~s}$ coincides with the third industrial revolution (IR 3.0) and the process of automation, computers, and electronics. According to Aziz Hussin (2018), during the third industrial revolution (IR 3.0), electronics and information technology are used to automate production. Despite IR 2.0, industrial revolution 3.0 is integrated with the basic steps in ICT (Diwan, 2017). There is also a revolution on the growing trends of computers and electronics. According to Diwan (2017), there is a jump between the market employability demand and education developments. Therefore, it is assumed that the first steps of electronic technology are integrated with teaching and learning in this period.

\subsubsection{Methods Associated with Education 3.0}

In this period, scientific methods are developed. The term scientific method has emerged by the ongoing enhancements in the fields of psychology and linguistics (Krashen \& Terrell, 1983). According to Terrell (1986), the scholars developed scientific methods based on the potentials of linguistics and psychology in teaching and learning. Scientific methods are also called student-centered approaches. In the context of language teaching and learning, there are scientific methods such as community language learning (CLL). In this method, the goal for language learning is that students typically have a conversation using their native language (Roth, 2013). The teacher helps learners to express what they want to say by giving them the target language translation. These words are recorded, and when they are replayed, it sounds like a fairly fluid conversation.

According to Richards \& Rodgers (2001), total physical response (TPR) is also a scientific method. Applying TPP, the coordination of speech and action facilitates language learning. Grammar is taught inductively. Meaning is more important than form. Speaking is delayed until comprehension skills are established. Effective language learning takes place in a low-stress environment. The role of the teacher is central. S/he chooses the appropriate commands to introduce vocabulary and structure. The learner is a listener and a performer responding to commands individually or collectively. Learning is maximized in a stress-free environment. There are also other 
scientific methods such as Suggestopedia, The Silent Way (SW), The Natural Approach (NA), and finally, Communicative Language Teaching (CLT) which opens the way for the post-methods area (Kumaravadivelu, 1994).

\subsubsection{Theories Associated with Education 3.0}

The core values of scientific methods are interactive rather than repetitions. Since scientific methods are developed by the potential use of the fields of psychology and linguistics (Krashen \& Terrell, 1983). Hence, there is a concern on the way that language is learned through the process of information in the brain and oral interaction. This is why the theory of mentalism and the intending idea of UG (Universal Grammar) was raised by Noam Chomsky (1960s). Despite the behaviorism theory of learning, mentalists believed that learning is an internal process of information that cannot be restored by imitations (Richards \& Rodgers, 2001). Language teaching methods such as natural approach and TPR are aligned with this theory of learning. The theory requires the teachers and learners to the acceptance of the error as part of the learning procedure and developmental order.

\subsubsection{Generation Classifications Associated with Education 3.0}

Children during Education 3.0 are Baby Boomers Generation from 1948 to 1963 , Generation X from 1964 to 1979 , and Generation Millennials from 1980 to 1995. According to Wey \& Sutton (2002), the social context in which a generational group develops impacts their personality and a person's feelings towards authority, their values and beliefs about organizations, their work ethic, why and how they work, and their goals and aspirations for their worklife. It has also suggested that each generation is likely to develop distinct preferences or traits that distinguish their feelings toward work and what they desire from work (Jurkievicz \& Brown, 1998; Kupperschmidt, 2000).

\subsubsection{Skills Associated with Education 3.0}

During the third industrial revolution, there are certain skills required by schools, universities, and marketplace. They are a generation after the second world war (Wey \& Sutton, 2002), and more than anytime else, now they needed communication. That is why scientific methods are developed in language learning that concentrates on the communication competencies of the learners (Richards \& Rodgers, 2001). International language learning also becomes a matter in most countries. According to OECD. (2018), the emergence of television also requires learners to another new skill of media. Hence, skills such as communications skills, computer skills, comprehension skills, technology skills, and translation skills are dominant skills for employability.

\subsection{Education 4.0}

The fourth generation of education (Education 4.0) during the $2000 \mathrm{~s}$, however, is integrated with the industrial revolution (IR 4.0) of cyber-physical systems, the internet of things, and networks which has also been called the intelligent generation. According to Aziz Hussin (2018), the industrial revolution (IR 4.0) is beyond the enhancement of the third industrial revolution, in which the advancement of new technologies blurs the lines between the physical, digital, and biological worlds. The new technologies evolve at an exponential pace and there is no historical precedent that marked the beginning of the evolution, hence, being called disruptive technologies. These advancements are led by the emergence of artificial intelligence, robotics, the internet of things, autonomous vehicles, bio and nanotechnology, 3-D printing, material science, quantum computing, and energy storage (Diwan, 2017).

According to Watson (2017), Education 4.0 is based on the belief that content is freely and readily available. It is self-directed and interest-based learning where problem-solving, innovation, and creativity drive education are valued. Indeed, Education 4.0 is a response to the needs of IR 4.0 where humans and technology are aligned to enable new possibilities (Rumbidzai et al., 2020). Fisk (2017) also explained that the new vision of learning promotes learners to learn not only skills and knowledge that are needed but also to identify the source to learn these skills and knowledge. This is how technology matters in this period of education (Rahim \& Sandaran, 2020).

\subsubsection{Methods Associated with Education 4.0}

According to several studies, Watson (2017), Roth (2013), OECD (2018), Fisk (2017), Diwan, (2017), and Datin (2017), Education 4.0 offers certain concepts for teaching and learning. Firstly, it provides anytime anywhere education. Secondly, it discusses personalized to individual learning. Thirdly, it indicates that students have a choice in determining how they want to learn. Fourth, it exposes students to more project-based learning. Fifth, it intends students to be exposed to more hands-on learning through field experiences such as internships, mentoring projects, and collaborative projects. Sixth, it exposes students to data interpretation in which they are required to apply their theoretical knowledge to numbers and use their reasoning skills to make inferences based on logic and trends from given sets of data. Seventh, students' assessment is different and the conventional platforms that assess students may become irrelevant or insufficient. Eight, students' opinions will be considered in designing and updating the curriculum. Nine, students will become more independent in their learning, thus forcing teachers to assume a new role as 
facilitators who will guide the students through their learning process.

This is how the concept of post-methods comes in. By some means, post-methods are called the end of methods. At around the same time, Kumaravadivelu (1994), identified what he called the 'post method condition, a result of the widespread dissatisfaction with the conventional concept of method. Rather than subscribe to a single set of procedures, post-method teachers adapt their approach under local, contextual factors, while at the same time being guided by some 'macro strategies. Two such macro-strategies are maximizing learning opportunities and promoting learners autonomy. According to Prabhu (1990), there is no one method, but that individual teacher's fashion an approach that accords uniquely with their sense of plausibility.

\subsubsection{Theories Associated with Education 4.0}

Learners in this age of education decide on their learning, therefore, constructivism is applied. Constructivism is based on the idea that people actively construct or make their knowledge, and that reality is determined by their experiences as a learner. John Dewey (1933 to 1998), is often cited as the philosophical founder of this approach. Bruner (1990) and Piaget (1972), are considered the chief theorists among the cognitive constructivists, while Vygotsky (1978), is the major theorist among the social constructivists. The dominant metaphor of this theory is order-free. Since there is no single method in this age, the theory is a method-free theory. Applying this theory, learning accurse through the comprehensive input from instruction and output. It ultimately focuses on form rather than meaning.

\subsubsection{Generation Classifications Associated with Education 4.0}

Children during Education 4.0 are called Generation Z. This generation is led through the stream of the internet of things, networks, cyber technology from 1996 to 2009. According to Wong et al. (2008), generation $\mathrm{Z}$ has grown up with technology and is used to having technology as a large part of their life. Likely, they are seen to be comfortable with change and are less likely to see job security as an important factor in the workplace (Hart, 2006).

\subsubsection{Skills Associated with Education 4.0}

The cycle for skills development in this age of education is wider than any other generation due to the rapid revolution in ICT, and the paradigm shift in teaching and learning as well as marketplace employability requirements. Skills such as ICT skills, communication skills, and time management are the core skills of the students. However, the paradigm shift in education requires them to practice certain other important skills to cope with the educational circumstances. According to Wong et al. (2008), as employees, generation $\mathrm{Z}$ are typified as valuing skill development and enjoying the challenge of new opportunities. Therefore, critical thinking, creativity, collaboration, communications, and culture are the most applicable skills of this age of education (OECD, 2018).

\subsection{Education 5.0}

The fifth generation of education (Education 5.0) during 2020 has launched with efforts to empower AI (Artificial Intelligence) with consciousness. Therefore, Education 5.0 introduces a smart-curriculum that is integrated with the potential use of AI and ICT for educational development. Indeed, Education 5.0 is the response for ICT, AI, and biotechnology. According to Rumbidzai \& Maupa (2020), Education 5.0 is a new curriculum reform that would need the buy-in of educators for possible smooth implementation. There is also some requirements for transformation of the fifth generation of education (Education 0.5). The most basic requirement of Education 5.0 is $21^{\text {st }}$ century skills (Rahim \& Sandaran 2020). These skills can be classified into three basic categories such as Learning Skills, Literacy Skills, and Life Skills.

\subsubsection{Methods Associated with Education 5.0}

Since the Covid-19 pandemic has already shifted the paradigms towards the most flexible and selforiented learning and teaching, there is an urgent need for revising the pre-pandemic curriculums to a postpandemic. The post-pandemic area is a new view of educational orientations (Rahim \& Sandaran, 2021). There are online classes, smart applications, learning distantly, less expensive in compared to the traditional classrooms, and of course, learning focuses on the post-pandemic area.

When post-pandemic is discussed, still the methods for analyzing the unlimited online available knowledge is a matter. Hence, methods matter. In the early Education 4.0, it was believed that it is the end of teaching and learning methods. In the United States, many preferred homeschooling. The concept of deschoolization was springing out everywhere, but it is just a paradigm shift. According to OECD (2018), it is important to discuss methods for the future of education based on the use and integration of $\mathrm{AI}$ and ICT trends to address the learners need. According to Fisk (2017), Diwan (2017), OECD (2018), Rahim (2019), and Rahim \& Sandaran (2021), approaches, frameworks, and educational modules such as OBE, CEFR, and blended learning approaches can bridge Education 4.0 to Education 5.0.

\subsubsection{Theories Associated with Education 5.0}

In this age of education, teaching and learning theories are aligned with post-constructivism. Constructivist epistemologies focus on ethics as a system of values in the mind, even when previously co-constructed in a social context against which social 
agents compare the actions that they mentally plan before performing them (Roth, 2013). This approach is challenging, as it forces a wedge between thought and action, body and mind, universal and practical ethics, and thought and affect. Drawing on a fragment of a concrete classroom episode as an exemplary case, Roth (2013), develop and exemplify a postconstructivist discourse on ethics that centers on the dialogical relation of participants in the conversation and that overcome the problems of the constructivist approach which is also aligned with Education 4.0. This practical ethics is consistent with the dialectical (dialogical) conception of the world-as-event.

\subsubsection{Generation Classifications Associated with Education 5.0}

Based on the generation classifications, children in Education 5.0 area of teaching and learning from 2010 to 2025 are Alpha Generation. The educational needs of the Alpha Generation are different from the previous generations since they are involved in every phase of their learning process. According to OECD (2018), the educational needs of students from 2025 to 2050 are not yet predictable due to the growing enhancements of ICT, AI, and the growing fields of industry.

\subsubsection{Skills Associated with Education 5.0}

Introducing the skills of Education 5.0 requires a broad discussion. Even though, Covied-19 pandemic has outdated learning orientations and skills whiten the higher education institutions globally. Nationalwide lockdowns and new norms of social distancing have motivated scholars and universities towards acquiring new skills. According to Rumbidzai \& Maupa (2020), Education 5.0 focuses on five pillars which are Research, Teaching, Community Service, Innovation, and Industrialization.

In addition, any educational transformation changes many concepts. In terms of Education 5.0, some of the concepts have already changed. The concept of (Study-Hard) has changed to (StudySmart). The concept of (Work-Hard) has changed to (Work-Smart). The concept of (Change) has changed to (Transform). The concept of (Invent) has changed to (Innovate). The concept of (Job Ready Education) has been changed to (Life Ready Education). These concepts have also provided an opportunity to the higher education institutions to transform Education 5.0 and prepare learners for the post-pandemic of Covid-19.

\section{Research Methodology}

The study conducted a qualitative critical document analysis using public records, personal documents, and physical evidence. The public records included the official, ongoing records of educational trends in universities. For example, the transformation in course policies, curriculums, syllabi and layout of the classrooms, strategic plans of the international universities, assessment methods, and annual reports. Also, personal documents included first-person accounts of individual's actions, experiences, and beliefs. For instance, websites, Facebook posts, reflections, journals, and newspapers. Whereas, physical evidence included Physical objects found within the study setting. Physical evidence includes posters, agendas, handbooks, exam sheets, and training materials. These three sources of data are used to provide credibility to the research and fulfill the triangulation assumption of the qualitative study (O’Leary, 2014).

\subsection{Data Collection}

The study created a list of texts and dataset to explore from the public records, personal documents, physical evidence. Then the study gathered relevant texts and documents and developed the organization and management scheme. The study followed historical patterns of the topics to consider the relationships of the key concepts. Analyzing the documents also incorporated coding content into themes similar to how focus group or interview transcripts are analyzed (Bowen, 2009).

\subsection{Data Analysis}

The study applied qualitative critical document analysis which has evolved into one of the most used qualitative methods across several disciplines (Kuckartz, 2014 and Mayring, 2010). Critical document analysis is a form of qualitative research in which documents are interpreted by the researcher to give voice and meaning around an assessment topic (Bowen, 2009). Its straightforward structure and procedure enable the researcher to adapt the method to his or her special case nearly to every need. Thematic illustration is provided after transcribing and coding the themes and subthemes based on the main research questions of the study.

In this particular study, the following data analysis procedures are observed.

Figure 3.1 Data Analysis Procedures

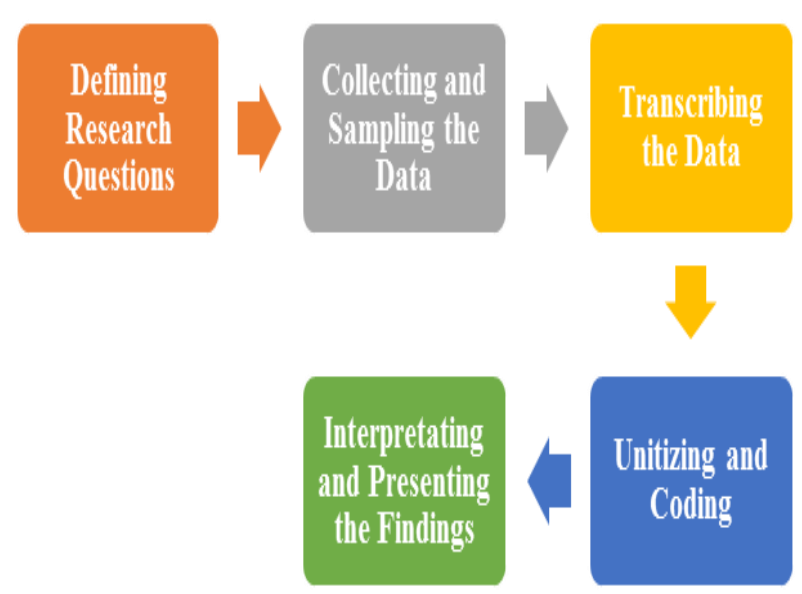


Based on the stated research questions of the study, data from public records, personal documents, and physical evidence such as websites, journals, academic reports, and exam sheets are collected. After transcribing the data, related codes are sorted to illustrate the themes. Finally, the analysis is presented thematically.

\section{Findings and Discussions}

To investigate Education 5.0 and the higher education circumstances in Afghanistan; determine the pre-requisite skills for educational transformation, and demonstrate how Education 5.0 helps students in post-pandemic, findings are presented and discussed in the following themes.

\subsection{Education 5.0 and the Higher Education Circumstances in Afghanistan}

Education 5.0 provides a comprehensive pathway for learners to observe the progress after the end of every course (Jonathan, 2021). Indeed, Education 5.0 is not only implemented to share knowledge, but also to help learners get inspired, to explore, and discover many creative ideas by themselves. In terms of teaching and learning methods, clear and detailed instructional methods are provided for each lesson to ensure that learners can acquire and apply knowledge into practice easily. According to Jonathan (2021), Education 5.0 is now a reality having been adopted by the fundamental values of teaching, research, community service, innovation, and industrialization.

Therefore, teaching as a profession and education in general must simply adapt to the new circumstances of change. A change that requires a transition from (Curriculum Deliverer) to (Learning Coach). The new function is to fuel the natural passion and genius of the student, rather than being the protectors of knowledge, forcing students down a pre-constructed road that is built for the masses.

According to Rüfenacht (2021), learners have to be encouraged to question the knowledge and methods taught by teachers and to find new innovative insights as an individual as well as a collective. In the context of Afghanistan, it is recognized that many teachers already fulfilling this particular change. However, the evidence shows that the majority of the teachers express their inability to fulfill this role of change not from a lack of desire, but because of the outdated and obsolete limitations of the systems in which they work in the institutions.

According to the evidence, most of the schools and higher education institutions of Afghanistan are still functioning through the Education 1.0 model. Although many would deny that they are focusing on an essentialist-based curriculum with related approaches of teaching and testing. The findings show that the higher education of Afghanistan is $80 \%$ exam-oriented which is ultimately aligned with Education 1.0 of the pre-1800s in terms of generations classification, learning theories, teaching and learning methodologies, and skills.

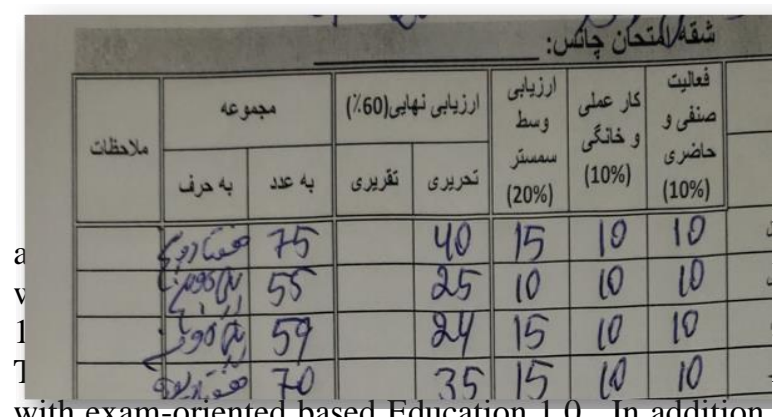
with exam-oriented based Education 1.0. In addition, the data shows that there is a resistance to change due to the inclusive traditional practices and classic infrastructures in the institutions. Despite the efforts for implementing OBE, SCL, and e-learning in the higher education institutions by the ministry of higher education of Afghanistan, the actual practices are aligned with an essentialist-curriculum of teaching and testing.

Comparing the higher education circumstance of Afghanistan with the on-going global education, the post-pandemic area will be very challenging for students. Since the requirements of the marketplace is disregarded to the potentials of the current educational practices. Applying the traditional education designs, students only acquire limited skills and knowledge of the pre-pandemic. Whereas, the skills and knowledge of the post-pandemic are quite different. Therefore, students who are learning through Education 1.0 are not capable to Education 5.0 platforms. According to Rumbidzai \& Maupa (2020), Education 5.0 is beyond the ongoing educational practices of all periods. Indeed, Education 5.0 is the redefinition of the curriculum as a whole and transformation of a smartcurriculum that fulfills the needs of 21st-century learners based on the innovative content of AI and ICT to provide learners for learning smart and working smart.

\subsection{The Pre-Requisite Skills for Educational Transformation}

The dominant skills of the classic curriculum of teaching and testing are reading skills, memorization skills, repetition drills, and corrections which is aligned with Education 1.0. This module of education is similar to the first generation of the Web, a largely 
one-way process of information or knowledge. The following figure illustrates the actual teaching and learning practices of the $21^{\text {st }}$ century and the gaps in teaching and learning practices of Afghanistan. It also indicates the skills required for transforming into Education 5.0.

Figure 4.2 $21^{\text {st }}$ Century Skills Framework

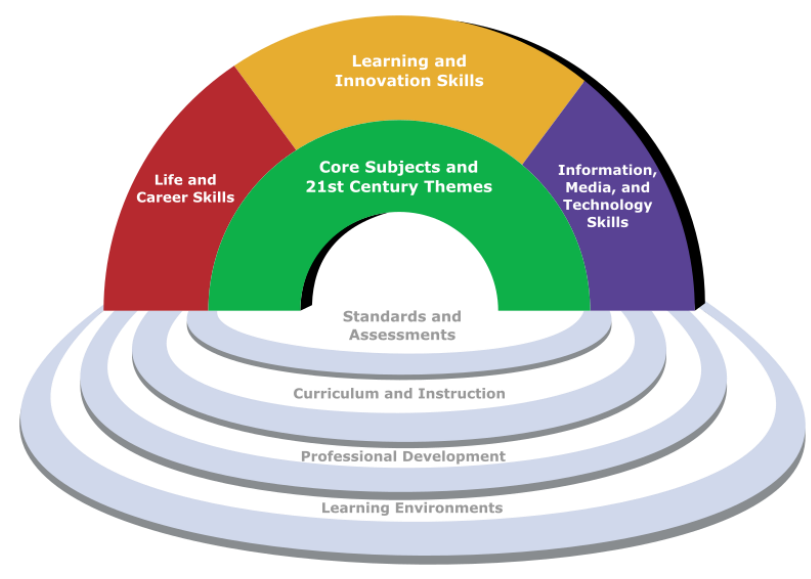

Source: Charles Fadel and Krishna Chaitanya Velaga - File: Framework for 21st Century Learning.jpg.

Figure 4.2 illustrates teaching and learning in $21^{\text {st }}$ century that takes place through the use of the core skills in the framework. Fundamentally, life and career skills, learning and innovation skills, and information media, and technology skills are facilitating learners and educators to accomplish their educational assumptions.

Assessments and standards, curriculum and innovation, professional development, and learning environments are followed by fundamental skills such as skills of learning, skills of technology, and skills of life (Stauffer, 2021). Therefore, the following threecategories of skills help the higher education institutions to prepare the students for post-pandemic area and accelerate Education 5.0 transformation in higher education of Afghanistan.

\subsubsection{Learning Skills}

Critical thinking and analysis, complex problem solving, creativity and innovation, communication and collaboration, and cultural skills are the core skills of learning in Education 5.0. These $21^{\text {st }}$-century skills align students with the global education and employability during the post-pandemic of Covid-19 (Stauffer, 2021).

\subsubsection{Literacy Skills}

Since Education 5.0 is aligned with industrial revolution 5.0 and the rapid enhancements of ICT and AI, there are three core literacy skills that help learners to be literate in $21^{\text {st }}$ century (Stauffer, 2021).

\subsubsection{Information Literacy}

Information literacy is the understanding of facts, figures, statistics, and data. Information literacy is a foundational skill which helps students to understand the facts, especially the data points that they encounter online. More importantly, it teaches the learners on how to distinguish the fact from fiction.

\subsubsection{Media Literacy}

Media literacy is the understanding of methods and outlets in which information is published. Media literacy is the practice of identifying publishing methods, outlets, and sources while distinguishing between the ones that are credible and the ones that are not. Indeed, it is distinguishing the authentic from the fake. Just like the previous skill, media literacy helps learners to find the truth in a world that is saturated with information.

\subsubsection{Technology Literacy}

Technology literacy is the understanding of machines that make the Information Age possible. technology literacy goes another step further to teach learners about the machines involved in the Information Age. For instance, computers, cloud programming, and mobile devices that have become more important to the world and the world needs more people to understand these concepts accurately. Technology literacy gives students the basic information they need to understand what gadgets perform, the tasks and why. This understanding removes the intimidating feeling that technology tends to have. According to OECD (2018), if learners do not understand how the technology works, it might look to be magic or mythical, but technology literacy unmasks the high-powered tools that run today's world. As a result, students can adapt to the world more effectively.

\subsubsection{Life Skills}

It is not only about learning and being literate in the age of new technologies, but life skills help students in post-pandemic area as well. Since life might be quite different even if the national and international lock-downs are eased. Skills such as flexibility and adaptability, initiative and selfdirection, social and cross-cultural skills, productivity and accountability, and leadership and responsibility help students to survive better in the post-pandemic area.

\section{Conclusion}

Analyzing the documents critically, the study discussed Education 1.0, Education 2.0, Education 3.0, Education 4.0, Education 5.0, and the educational circumstances in higher education in Afghanistan. The result shows that the higher education institutions of Afghanistan prepare students with traditional curriculums of teaching and testing which do not address the needs of $21^{\text {st }}$-century employability in the marketplace. The findings determine Education 5.0 as 
a smart-curriculum reform in the context of higher education which is aligned with trends in AI and ICT and enables students for smart education in the postpandemic area. It also demonstrates the $21^{\text {st }}$-century skills such as learning skills, literacy skills, and life skills that prepare learners and the higher education institutions for transforming Education 5.0. Overall, the study contributes to the alignment of employability in $21^{\text {st }}$-century marketplace by transforming Education 5.0 in higher education of Afghanistan to help students in the post-pandemic of Covid-19.

\section{Acknowledgement}

This research is dedicated to the Ministry of Higher Education of Afghanistan for their best in preparing the new generation of Alpha. I also thank my colleagues at Kunduz University for providing insight and expertise that greatly assisted during the research.

\section{References}

Adams, S.J. (2000). Gen X: How Understanding This Population Leads to Better Safety

Professional Safety, 45 (1), 26-9.

Aziz Hussin, A. (2018). Education 4.0 Made Simple: Ideas for Teaching. International Journal of Education \& Literacy Studies. 6(3), 92-98. DOI: http://dx.doi.org/10.7575/aiac.ijels.v.6n.3p.92.

Bowen, G. A. (2009). Document Analysis as a Qualitative Research Method. Qualitative Research Journal, 9(2), 27-40.

Bradford, F.W. (1993). Understanding Gen X. Marketing Research,l 5 (1). 54.

Chomsky, N. (1959). Language and Mind. New York: Cambridge University Press.

Datin, P., I. \& Dr. Siti H., T. (2017). Malaysia Higher Education 4.0. Director-General Department of Higher Education Ministry of Higher Education.

Diwan, P. (2017). Is Education 4.0 an imperative for success of 4th Industrial Revolution. Retrieved from: https: //medium.com/ @ pdiwan/iseducation- 4-0-an-imerative- for- success-of4th-industrial-revolution- 50c31451e8a4.

Fadel, Ch. (2008). 21 $1^{\text {st }}$-Century Skills: How Can You Prepare Students for the New Global Economy? OECD/CERI Paris: Global Lead, Education Cisco Systems, Inc.

Fisk, P. (2017). Education 4.0 - the future of learning will be dramatically different, in school and throughout life. http://www.thegeniusworks.com/2017/01/futureeducation-young-everyone-taught-together.
Jonathan, E. (2021). Education 5.0 - towards problem-solving and value creation. Retrieved from: http://www.mhtestd.gov.zw/?p=3501.

Harari, Y. N. (2019). 21 Lessons for the $21^{\text {st }}$ century. Vintage.

Hart, S. L. (2006). Worlds in collision. Journal of Organizational Excellence. 25. (3). DOI: https://doi.org/10.1002/joe.20097.

Krashen, S., D., \& Terrell, T. D. (1983). The natural approach: Language acquisition in the classroom. London: Prentice-Hall Europe.

Kumaravadivelu, B. (1994). The Post method condition: Emerging strategies for second/foreign language teaching. TESOL Quarterly, 28(1), 27-48.

O'Leary, Z. (2014). The essential guide to doing your research project (2nd ed.). Thousand Oaks, CA: SAGE Publications, Inc.

OECD. (2018). The Future of Education and Skills Education 2030. Directorate for Education and Skills-OECD 2 rue André Pascal - $\quad 75775$ Paris Cedex 16-France.

Prabhu, N. S. (1990). There is no Best Method-Why? TESOL Quarterly, 24(2), 161-176.

Rahim, M. N. (2019). The Use of Blended Learning Approach in EFL Education. International Journal of Engineering and Advanced Technology, 8(5C), 1165-1168. DOI: https://doi.org/10.35940/ijeat.e1163.0585c19.

Rahim, M. N. (2019). Blended Learning Application in Teaching \& Learning English as a Second Language: A Conceptual Paper. $2^{\text {nd }}$ Language and Communication Postgraduate International Seminar (LCPIS) Proceedings, ISBN 978-967-2171-73-7, 36-39.

Rahim, M. N., Hui, Y. K., Johari, M. W., Md Noor, N., \& Abu Bakar, Z. (2019). Mobile Learning Apps for Language Listening Skill. Proceeding of New Academia Learning Innovation (NALI 2019) Exhibition \& Competition, eISBN 978967-2171-94-2, 147-150.

Rahim, M. N., \& Sandaran, S. C. (2020). EFL Teachers' Perceptions of the Barriers and Opportunities for Implementing eLearning at Afghanistan Universities. Universal Journal of Educational Research, 8(11C), 97-104. DOI: https://doi.org/10.13189/ujer.2020.082311.

Rahim, M. N. (2021). The Relationship Between the Time Spent on Facebook and GPA Scores of Post-Graduates. International Journal of Multidisciplinary: Applied Business and Education Research, 2(1), 94-102. http://ijmaberjournal.org/index.php/ijmaber/articl e/view/74. 
Rahim, M. N., \& Sandaran, S. C. (2021). The Implementation of E-learning Approach in EFL Education: An Organizational Perspective. Universe International Journal of Interdisciplinary Research, 1(9), 156-168. DOI: $\quad$ http://www.doi-ds.org/doilink/03.202198353846/UIJIR.

Rahim, M. N., \& Chandran, S. C. (2021). Investigating EFL Students' Perceptions on Elearning Paradigm-Shift During Covid-19 Pandemic. Elsya: Journal of English Language Studies, 3(1), 56-66. DOI: https://doi.org/10.31849/elsya.v3i1.5949.

Richards, J. C., \& Rodgers, T. S. (2001). Approaches and methods in language teaching. Cambridge: Cambridge University Press.

Roth, W., M. (2013). Toward a Post-Constructivist Ethics in/of Teaching and Learning Pedagogies: An International Journal, 8, 103-125.

Rüfenacht, M. (2021). Education 5.0-Why We Need to Adjust the Education System. Medium. https://mattiasuisse.medium.com/education-5-0why-i-think-we-need-to-adjust-the-educationsystem-4a669b26396d.

Rumbidzai, M., D. \& Maupa., B., B. (2020). Perception of Educators Towards the Adoption of Education 5.0: A Case of a State University in Zimbabwe. East African Journal of Education and Social Sciences.1(2)43-53. DOI: https://doi.org/10.46606/eajess2020v01i02.0020.

Stauffer, B. (2021). What Are 21st Century Skills? Digital Curriculum for CTE \&amp; Elective Teachers.

https://www.aeseducation.com/blog/what-are21st-century-skills.

Stern, H., H. (1983). Fundamental Concepts of Language Teaching. Oxford: Oxford University Press.

Terrell, T., D. (1986). Acquisition in the Natural Approach: The Binding/Access Framework. The Modern Language Journal. 70(3). 213- 227.

Twenge, J. M., Zhang, L. \& Im, C. (2004). It's Beyond My Control: A Cross-Temporal MetaAnalysis of Increasing Externality in The Locus of Control, 1960-2002. Personality and Social Psychology Review, 8 (3). 308-19.

Watson, R. (2017). Education: Future Frontiers. An essay commissioned by the NSW Department of Education. Occasional Paper Series.

Wey Smola, K. \& Sutton, C. D. (2002). Generational Differences: Revisiting Generational Work Values for the New Millennium. Journal of
Organizational Behavior, 23(4), 363- 382. DOI: https://doi:10.1002/job.147.

Wong, M., Gardiner, E., Lang, W. \& Coulon, L. (2008). Generational Differences in Personality and Motivation Do They Exist and What Are the Implications for the Workplace? Journal of Managerial Psychology,23 (8). 878-890. DOI: https://10.1108/02683940810904376.

Yu, H.C. \& Miller, P. (2003). The Generation Gap and Cultural Influence: A Taiwan Empirical Investigation. Cross-Cultural Management, 10 (3). 23-41. 